\title{
Neuropatia autonomiczna układu sercowo-naczyniowego w przebiegu cukrzycy - aktualny stan wiedzy
}

\section{STRESZCZENIE}

$\mathbf{N}$ europatia cukrzycowa, w tym autonomiczna neuropatia sercowo - naczyniowa, jest najczęstszym powikłaniem przewlekłym cukrzycy. Powoduje ona poważne konsekwencje zdrowotne i społeczne, prowadząc do istotnego skrócenia oczekiwanej długości życia u pacjentów z DM. Przez jej początkowo bezobjawowy rozwój jest często nierozpoznawana, a jedynie wczesne wykrycie neuropatii cukrzycowej daje realne szanse na zahamowanie jej postępu i zapobiegnięcie nieodwracalnemu uszkodzeniu nerwów. Najistotniejszym czynnikiem przeciwdziałającym rozwojowi neuropatii, hamującym jej występowanie oraz progresję, jest optymalizacja kontroli glikemii. W fazie zaawansowanej natomiast, pozostają jedynie próby leczenia objawowego.

Poniższy artykuł przedstawia przegląd dotychczasowej wiedzy na temat etiopatogenezy, objawów, terapii i najnowszych badań klinicznych dotyczących NSN.

\section{WPROWADZENIE}

Badania ostatnich lat potwierdziły że w etiopatogenezie cukrzycy (DM) odgrywają rolę zarówno czynniki genetyczne jak i środowiskowe. Ze względu na zwiększoną zachorowalność oraz śmiertelność, związaną z powikłaniami mikro- i makronaczyniowymi, mówi się o epidemii cukrzycy na świecie. Według ostatnich danych epidemiologicznych w 2014 r. żyło 422 mln ludzi z cukrzycą na świecie, a liczba ta stale wzrasta [1]. Do przewlekłych powikłań cukrzycy należą: nefropatia (jedna z głównych przyczyn hemodializ w krajach rozwiniętych) [2], retinopatia częsta przyczyna ślepoty czy neuropatia cukrzycowa. Neuropatia cukrzycowa (częsta przyczyna ślepoty) jest najczęstszym i stwarzającym najwięcej problemów, przewlekłym powikłaniem cukrzycy, związanym z największą chorobowością i umieralnością (odpowiada za 50-75\% amputacji nieurazowych) co stanowi ogromne obciążenie społeczne i finansowe w leczeniu cukrzycy [3]. Neuropatia cukrzycowa obejmuje szeroki zakres zaburzeń, należy tu bowiem zarówno neuropatia autonomicznego układu nerwowego (odpowiedzialna m.in. za powstanie zaburzeń rytmu serca, perystaltyki przewodu pokarmowego jak gastropareza czy impotencję) oraz polineuropatia obwodowa, która dotyczy nerwów obwodowych, prowadząc do rozwoju zaburzeń sensorycznych czy motorycznych [4]. Neuropatia autonomiczna sercowo-naczyniowa (NSN, ang. CAN - cardiovascular autonomic neuropathy) jest dysfunkcją autonomicznego układu nerwowego. Objawia się spoczynkową tachykardią, co za tym idzie nietolerancją wysiłku a z czasem hipotensją ortostatyczną. Zwykle wyprzedza rozwój innych przewlekłych powikłań cukrzycowych jak neuropatię obwodową, nefropatię czy retinopatię [5]. Równocześnie należy podkreślić że spośród przewlekłych powikłań DM najczęściej diagnozowana jest neuropatia cukrzycowa. W zależności od wieku, czasu trwania cukrzycy i stopnia kontroli metabolicznej szacuje się, że może dotyczyć nawet $90 \%$ pacjentów [6]. Tabela 1 przedstawia klasyfikację neuropatii występujących w cukrzycy.

Tabela 1. Kliniczna klasyfikacja neuropatii cukrzycowej

\begin{tabular}{|c|}
\hline $\begin{array}{l}\text { Uogólniona symetryczna polineuropatia } \\
\text { - przewlekła czuciowo-motoryczna } \\
\text { - autonomiczna (układu sercowo-naczyniowego, moczowego, przewodu pokarmowego) } \\
\text { - ostra czuciowa }\end{array}$ \\
\hline $\begin{array}{l}\text { 2. } \text { Ogniskowe i wieloogniskowe polineuropatie } \\
\text { - nerwów czaszkowych } \\
\text { - nerwów rdzeniowych } \\
\text { - } \text { ogniskowe neuropatie kończyn, w tym zespoły uciskowe } \\
\text { - } \text { proksymalna ruchowa (amiotrofia) }\end{array}$ \\
\hline
\end{tabular}

\section{lek. Joanna Gastol,}

\section{Łukasz Pawliński,}

\section{dr hab. med. Beata \\ Kieć-Wilk prof. UJ ${ }^{\bowtie}$}

Szpital Uniwersytecki w Krakowie, Katedra Chorób Metabolicznych, Collegium Medicum Uniwersytetu Jagiellońskiego

https://doi.org/10.18388/pb.2019_287

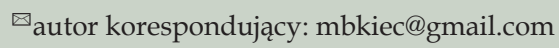

Słowa kluczowe: autonomiczna neuropatia sercowo - naczyniowa, cukrzyca, epigenetyka, leczenie

Lista stosowanych skrótów: AGEs - advanced glycation endproducts, końcowe produkty nieenzymatycznej glikacji białek; BP - ciśnienie tętnicze krwi; CAN - cardiovascular autonomic neuropathy; DM - cukrzyca; HR - częstość akcji serca; NSN - neuropatia autonomiczna układu sercowo-naczyniowego; PNS - parasympatyczny układ nerwowy; PTD - Polskie Towarzystwo Diabetologiczne; RAA - układ renina-angiotensyna-aldosteron; ROS - produkcja wolnych rodników; SNS - sympatyczny układ nerwowy; T1DM - typ 1 cukrzycy; T2DM - typ 2 cukrzycy

Podziękowania: Praca współfinansowana dzięki grantowi naukowemu fundowanemu przez Narodowe Centrum Nauki nr. UMO-2014/13/B/NZ4/00149). 
Neuropatia układu autonomicznego jest szczególnym rodzajem polineuropatii cukrzycowej, która na początkowym etapie (postać subkliniczna) może sprawiać trudności diagnostyczne. Nieprawidłowa regulacja autonomiczna może dotyczyć każdego z organów/układów narządów i obniżać jakość życia chorego. NSN wydaje się być najistotniejsza, gdyż znacząco wpływa na zachorowalność i śmiertelność sercowo-naczyniową. Zgodnie $\mathrm{z}$ definicją Komitetu ds. neuropatii cukrzycowej, ogłoszonej podczas konsensusu w Toronto cukrzycowa neuropatia autonomiczna układu sercowo-naczyniowego polega na nieprawidłowej kontroli autonomicznej systemu sercowo-naczyniowego w przebiegu cukrzycy po wykluczeniu innych przyczyn [6].

\section{EPIDEMIOLOGIA}

Przyjmuje się, że NSN może dotyczyć 20\% pacjentów z cukrzycą, choć jej rzeczywista częstość występowania jest trudna do oszacowania. Rozbieżności danych wynikają z różnic badanych populacji, użytych testów czy kryteriów diagnostycznych. Obecność NSN wzrasta z wiekiem (do $38 \%$ w typie 1 cukrzycy i $44 \%$ w typie 2 w wieku $40-70$ lat) i czasem trwania cukrzycy (do 35\% pacjentów z typem 1 i 65\% z typem 2 długotrwałej cukrzycy) [7]. Coraz częściej pojawiają się doniesienia o obecności neuropatii autonomicznej w stanie przedcukrzycowym (prediabetes) - 11,4\% chorych z mieszanymi zaburzenia metabolizmu węglowodanów (jak nieprawidłowa glikemia na czczo lub nietolerancja glukozy) [8]. Należy podkreślić również, że pacjenci z cukrzycą należą do grupy wysokiego i bardzo wysokiego ryzyka wystąpienia incydentów sercowo-naczyniowych. Ponadto cukrzyca zwiększa ryzyko rozwoju niewydolności serca. Współwystępowanie cukrzycy, choroby wieńcowej i przewlekłej niewydolności serca dramatycznie skraca szacowaną długość życia, bo aż o ok. 8 lat [9].

\section{PATOGENEZA NSN}

Badania nad patogenezą NSN, w przebiegu cukrzycy, wykazały jej wieloczynnikowy charakter. Jako czynniki ryzyka wymienia się wiek, czas trwania cukrzycy, stopień kontroli glikemii, współwystępowanie pozostałych powikłań mikroangiopatycznych (szczególnie w typie $1 \mathrm{cu}-$ krzycy). Neuropatia autonomiczna układu sercowo-naczyniowego pośród chorych z typem 2 cukrzycy jest ponadto związana z otyłością, nadciśnieniem tętniczym, nikotynizmem, dyslipidemią, oraz w różnym stopniu nasiloną hiperinsulinemią [10].

Przyjmuje się, że procesem zapoczątkowującym uszkodzenie neuronów jest utrzymująca się hiperglikemia. Wymienia się tu dwa mechanizmy patogenne hiperglikemii po pierwsze, nadmiar glukozy przekształcany przez reduktazę aldozową $\mathrm{w}$ sorbitol, a następnie we fruktozę. Akumulacja tych związków w neuronach w wyniku działania osmotycznego, stresu oksydacyjnego odpowiedzialnego za generowanie wolnych rodników, powoduje zmniejszenie biosyntezy metabolitów niezbędnych do funkcjonowania komórki nerwowej i prowadzi do jej apoptozy [11]. Hiperglikemia przyczynia się równocześnie do tworzenia produktów nieenzymatycznej glikacji białek (ang. AGEs - advanced glycation endproducts), co skutkuje indukcją stresu siateczki wewnątrzplazmatycznej i zwiększoną mitochondrialną produkcją wolnych rodników (ROS). Jest to przyczyną aktywacji procesów zapalnych, zaburzenia funkcji śródbłonka i przepuszczalności błon komórkowych [12]. W tym mechanizmie nieenzymatyczna glikacja białek zakłóca transport aksonów, zaburza procesy metaboliczne włókna nerwowego i synaps, również prowadząc do ich apoptozy [12]. Należy pamiętać że nie tylko wysokie wartości glikemii przyczyniają się do aktywacji procesów zapalnych u pacjentów z DM. Pojawia się coraz więcej doniesień na temat patogennego działania epizodów hipoglikemii, jako niezależnego czynnika aktywującego patogenne procesy zapalne $\mathrm{u}$ tych chorych [13]. Oprócz teorii metabolicznej rozwoju neuropatii cukrzycowej, obowiązuje również teoria naczyniowa. $\mathrm{W}$ teorii naczyniowej patologiczne zmiany $\mathrm{w}$ tętnicach nerwów obwodowych (vasa nervorum), zmiany reologiczne krwi i zaburzenia autoregulacji przepływu krwi prowadzą do ognisk niedokrwiennych i uszkodzenia nerwów u pacjentów z DM [14].

Dodatkowo jako czynniki sprawcze, bądź promujące rozwój NSN, wymienia się rolę zbyt niskiego/wysokiego poziomu witaminy $\mathrm{D}$, zaburzenia w gospodarce wapniowej prowadzące do apoptozy neuronów [15] oraz niedobory witaminy B12 [16].

Coraz więcej dowodów sugeruje, że złożone interakcje między genami i środowiskiem odgrywają kluczową rolę w uwarunkowaniu chorób cywilizacyjnych takich jak otyłość, choroba niedokrwienna serca, choroby nowotworowe czy cukrzyca i jej powikłania [17]. Najnowsze odkrycia sugerują, że epigenetyczne rozregulowanie ekspresji genów odgrywa znaczącą rolę w etiologii i patologii cukrzycy i jej powikłań [18]. Wieloletnie i wieloośrodkowe badania kliniczne (UKPDS, DCCT-EDIC) udowodniły, że szkodliwe skutki wczesnego narażenia na hiperglikemię (i hiperlipidemię) utrzymywały się przez lata mimo uzyskania poprawy wyrównania metabolicznego, w tym normalizacji glikemii [19]. Stwierdzono utrzymującą się progresję zmian narządowych u pacjentów z cukrzycą pomimo uzyskania poprawy kontroli metabolicznej cukrzycy [19]. Obserwacje te dotyczą chorych z DM typu 2 (T2DM), dotychczas nie przeprowadzono tak dużych i reprezentatywnych badań dla pacjentów z cukrzycą typu 1 (T1DM). Odwracalne, ale utrzymujące się przez dłuższy czas, kluczowe modyfikacje epigenetyczne; wynikająca z nich modyfikacja ekspresji genów i konsekwencje dla funkcjonowania sieci komórkowych (zwłaszcza dla komórek $\beta$ trzustki i śródbłonka) po nawet krótkotrwałej ekspozycji komórek na wysokie stężenia glukozy zostały odkryte niedawno i opisane jako "pamięć metaboliczna". [20-21]. Początkowo sądzono że wynikały one głównie ze zmian poziomu metylacji DNA jednakże dalsze badania wykazały kolejne czynniki epigenetyczne odgrywające potencjalną rolę w rozwoju "pamięci metabolicznej" jak szczególne polimorfizmy genów kodujących mikroRNA [22-23] predysponujące do rozwoju NSN. Tak więc zmiany epigenetyczne w poszczególnych genach docelowych mogą wyjaśnić przyspieszony rozwój powikłań narządowych nawet po skutecznym leczeniu hipoglikemizującym. 
Tabela 2. Najczęściej obserwowane objawy związane z NSN

\begin{tabular}{|l|}
\hline Spoczynkowa tachykardia \\
\hline Nietolerancja wysiłku \\
\hline Utrata zmienności rytmu serca \\
\hline Non-dipping, reverse dipping \\
\hline Nadciśnienie tętnicze \\
\hline Niedociśnienie ortostatyczne \\
\hline Nieprawidłowa wrażliwość baroreceptorów \\
\hline Sztywność tętnic \\
\hline Wydłużenie QT, arytmie \\
\hline Dysfunkcja i przerost lewej komory (LV) \\
\hline Ciche niedokrwienie miokardium \\
\hline
\end{tabular}

Powyższe mechanizmy wiodą do uszkodzenia neuronów zarówno obwodowych jak i w układzie bodźcotwórczym serca. Jednym z nerwów ulegającym najwcześniej uszkodzeniu, w przebiegu autonomiczej neuropatii cukrzycowej, jest nerw błędny. Odpowiada on za $75 \%$ aktywności przywspółczulnej całego organizmu, w tym w obszarze mięśnia sercowego [5]. Początkowo obserwuje się objawy związane z przewagą układu współczulnego jak tachykardia (akcja serca 90-103 uderzeń/min) i powoli narastające zmniejszenie rezerwy sercowej. Z czasem uszkodzeniu ulega układ współczulny a pacjent rozwija pełen obraz kliniczny NSN z nietolerancją wysiłku fizycz- nego, nieprawidłowym ciśnieniem tętniczym, nasiloną tachykardią oraz nieprawidłową objętością wyrzutową lewej komory serca. W postaci zaawansowanej rozwija się dodatkowo hipotensja ortostatyczna, definiowana jako obniżenie ciśnienia skurczowego o przynajmniej $20 \mathrm{mmHg}$ lub rozkurczowego o $10 \mathrm{mmHg}$ w trakcie 3-minutowego testu pionizacyjnego, przy zmianie pozycji ciała z leżącej na stojącą [24]. Tabela 2 przestawia najczęściej obserwowane objawy kliniczne związane z NSN (Tabela 2). Dodatkowo wykazano, że przewlekła aktywacja układu współczulnego w przebiegu NSN przyczynia się do przebudowy miocytów i zaburzenia ich funkcji co stanowi niezależny mechanizm rozwoju niewydolności serca u chorych z DM. NSN może doprowadzić również do zaburzeń rozkurczu lewej komory w mechanizmie aktywacji układu renina-angiotensyna-aldosteron (RAA) [25].

\section{DIAGNOSTYKA}

Złotym standardem diagnostyki w kierunku NSN pozostaje wykonanie testów tzw. baterii Ewinga [6]. Badanie polega na ocenie zmienności rytmu serca oraz ciśnienia tętniczego krwi w odpowiedzi do prowokowanych manewrów, tj. głębokie oddychanie, pionizacja, manewr Valsalwy (Tabela 3). Aby rozpoznać NSN konieczne jest stwierdzenie co najmniej dwóch nieprawidłowych rezultatów spośród wykonanych testów. Na podstawie powyższych testów dokonywany jest również staging, w zależności od ilości stwierdzonych nieprawidłowości. $[6,26]$. Rycina 1 przedstawia schemat diagnostyki w kierunku NSN. Zgodnie z zaleceniami Polskiego Towarzystwa Diabetologicznego (PTD), podobnie jak w pozostałych powikłaniach przewlekłych cukrzycy, obowiązuje aktywny screening w kierunku NSN [27].

Tabela 3. Bateria testów Ewinga - narzędzie diagnostyczne NSN

PNS - parasympatyczny układ nerwowy, SNS - sympatyczny układ nerwowy, HB - uderzenia serca, HR - akcja serca, SBD - skurczowe ciśnienie tętnicze krwi, $\mathrm{DBP}$ - rozkurczowe ciśnienie tętnicze krwi, BP - ciśnienie tętnicze krwi. Tabela opracowana w oparciu o [26].

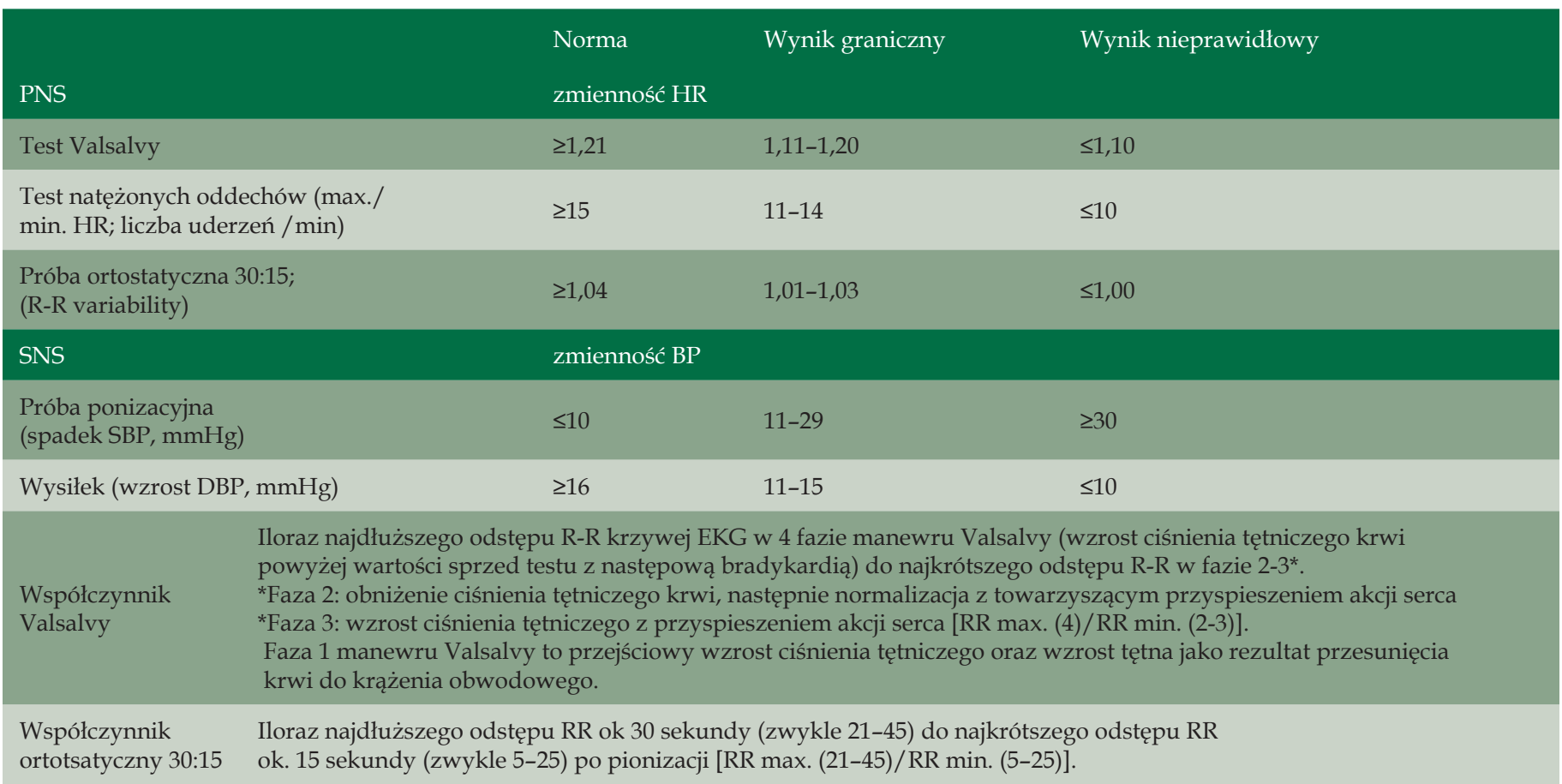




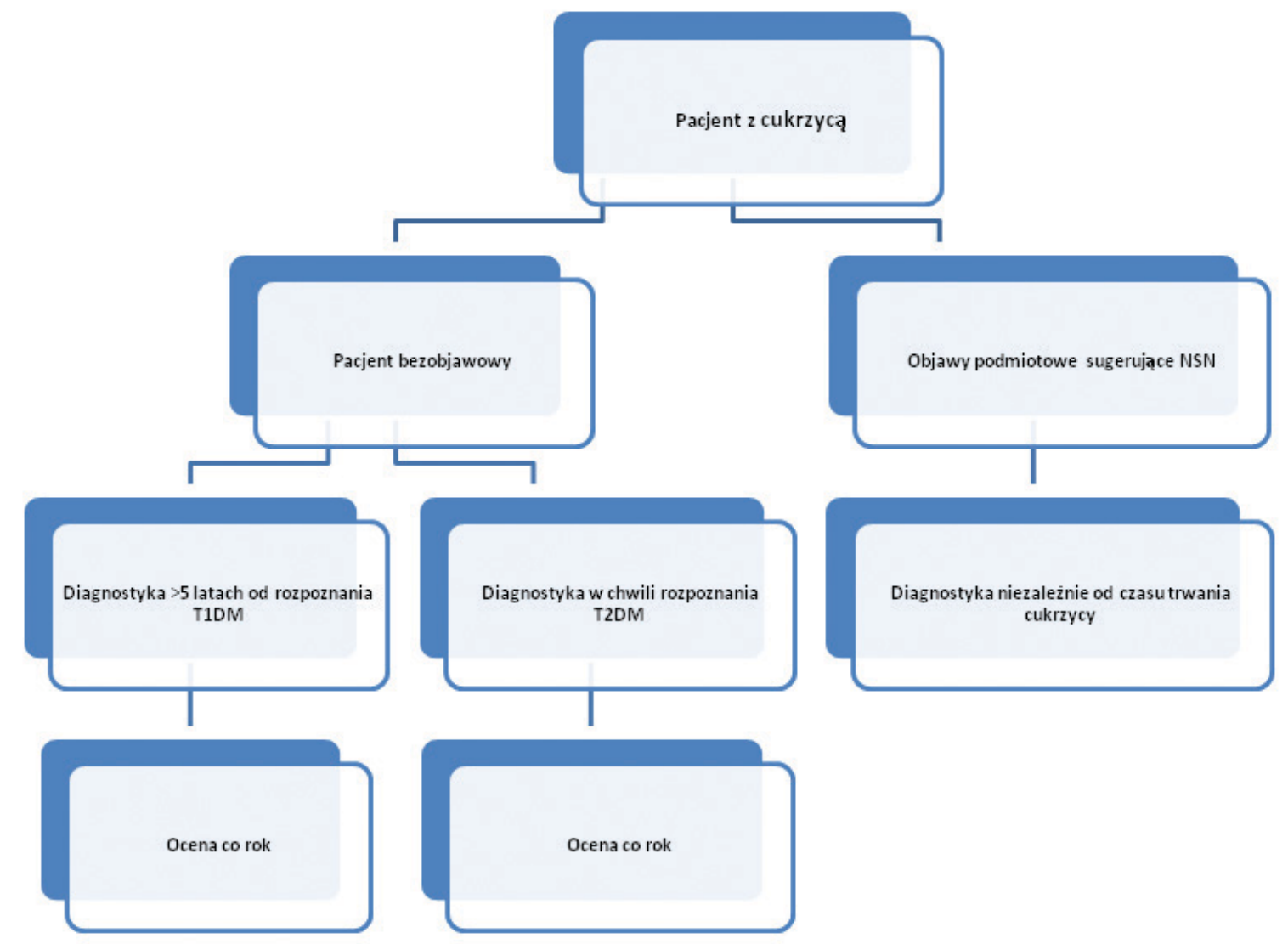

Rycina 1. Diagnostyka w kierunku NSN. Rysunek opracowano w oparciu o Zalecenia Polskiego Towarzystwa Diabetologicznego z 2019 r.

\section{PROFILAKTYKA I LECZENIE}

Z uwagi na wieloczynnikową patogenezę NSN, w terapii konieczne jest również podejście wielokierunkowe, które obejmuje modyfikację stylu życia (dieta, aktywność fizyczna, redukcja masy ciała), kontrolę metaboliczną przy zastosowaniu coraz nowocześniejszych preparatów farmakologicznych jak i próby leczenia przyczynowego.

\section{REDUKCJA MASY CIAŁA}

Zarówno otyłość, jak i sama cukrzyca typu 2, związana jest z nadaktywnością układu sympatycznego oraz redukcją zmienności rytmu serca. Dostępne badania (w przewarzającej mierze dotyczące otyłych pacjentów bez cukrzycy, w mniejszym stopniu chorych z typem 2 cukrzycy) udowadniają, że redukcja masy ciała (nawet umiarkowana), niezależnie jak została osiągnięta (modyfikacja stylu życia, operacja bariatryczna, dieta restrykcyjna) związana jest z poprawą wskaźników parasympatycznych, zmiennością rytmu serca i redukcją aktywności układu sympatycznego [28-29].

\section{DIETA}

Zastosowanie diety ubogokalorycznej u otyłych pacjentów z T2DM przez 8 tygodni wiąże się z poprawą parasympatycznej regulacji rytmu serca niezależnie od konsumpcji czerwonego mięsa czy zawartości błonnika [30]. Z drugiej strony jednak nie można wykluczyć, że poszczególne składniki diety nie wywierają wpływu na układ autonomiczny a obserwowany efekt wynika jedynie ze zmniejszenia masy ciała pacjentów [31-32].

\section{AKTYWNOŚĆ FIZYCZNA}

Znacząca większość danych dotyczy chorych z T2DM, równocześnie należy zaznaczyć że badania te przeprowadzano na niewielkich grupach chorych. Ponadto mnogość różnych i równoczesnych interwencji u tych chorych czy też różnorodność użytych do oceny wskaźników, utrudnia ujednolicenie wniosków. Aktywność fizyczna jest jednym $\mathrm{z}$ elementów terapii T2DM z uwagi na uznane benefity $\mathrm{w}$ zakresie ogólnej sprawności organizmu, poprawy insulinowrażliwości, co za tym idzie kontroli metabolicznej oraz redukcji wskaźników stanu zapalnego [33]. Wydaje się, że regularna aktywność fizyczna złożona z ćwiczeń aerobowych jak i siłowych poprawia zmienność akcji serca (HRV) u pacjentów z typem 2 cukrzycy [34]. Pojawiają się doniesienia dotyczące wpływu jogi i pranajamy na funkcję układu autonomicznego. Ten szczególny rodzaj aktywności fizycznej w połączeniu z ćwiczeniami oddechowymi, regulacją toru oddechu wydaje się korzystnie wpływać na wrażliwość baro- i chemoreceptorów oraz obniżać spoczynkową akcję serca [35].

\section{KONTROLA METABOLICZNA}

Badania DCCT i EDIC dostarczyły niezbitych dowodów, iż wczesna i intensywna kontrola glikemii u pacjentów z cukrzycą typu 1 jest istotnym czynnikiem zapobiegającym i spowalniającym rozwój neuropatii autonomicznej [36]. Eu- 
ropejskie jak i Amerykańskie towarzystwa diabetologiczne rekomendują uzyskanie jak najlepszego wyrównania metabolicznego od początku trwania cukrzycy, celem zapobiegania czy opóźnienia rozwoju przewlekłych powikłań u pacjentów z T1DM oraz złożone, wieloczynnikowe postępowanie uwzględniające różne czynniki ryzyka u pacjentów z T2DM [27]. Obserwacje przeprowadzone w naszej klinice, u pacjentów z cukrzycą typu 1 porównujące chorych leczonych intensywną insulinoterapią w modelu osobistej pompy insulinowej (CSII) z pacjentami leczonych przy użyciu penów insulinowych (MDI), wykazały istotnie niższy poziom $\mathrm{HbA1c}$ w grupie CSII. Jednocześnie, niezależnie od metody leczenia, $\mathrm{u}$ pacjentów z T1DM powikłanych NSN występowała istotnie gorsza kontrola metaboliczna pod względem glikemii, poziomu HbA1c [26]. Podobny związek stwierdzono w badaniu DCCT, w którym wykazano, że bardziej intensywne leczenie cukrzycy i lepsza kontrola metaboliczna zapobiegają rozwojowi powikłań DM [36].

\section{WPŁYW NOWYCH LEKÓW HIPOGLIKEMIZUJĄCYCH}

Coraz większą uwagę $\mathrm{w}$ terapii cukrzycy zwraca się nie tylko na efektywność leczenia hipoglikemizującego, ale i na bezpieczeństwo terapii. Jednymi z najnowszych doustnych leków hipoglikemizujących są flozyny (inhibitory kotransportera sodowo-glukozowego 2, SGLT2), których mechanizm działania jest niezależny od insuliny. Jako efekt działania dla całej klasy tych leków wymienia się zapobieganie rozwojowi i progresji niewydolności serca $(\mathrm{HF})$ oraz przewlekłej choroby nerek [37]. Środki te działają na proksymalne kanaliki nerkowe, ograniczając wchłanianie zwrotne glukozy i sodu, przez co zwiększają wydalanie tych substancji z moczem, przyczyniając się do glukozurii i obniżenia stężenia glukozy w osoczu. Na podstawie dużych badań klinicznych (tj. EMPAREG OUTCOME) wiadomym jest, że są to leki o działaniu kardio- i nefroprotekcyjnym [37-38]. Flozyny obniżają ciśnienie tętnicze krwi, spoczynkową akcję serca, zwiększają produkcję peptydów natriuretycznych i erytropoetyny, zmniejszają wolemię, oraz lokalną produkcję fibroblastów prowadzącą do włóknienia nerek. Ponadto sprzyjają spadkowi masy ciała co sprawia, że nadaktywny układ sympatyczny ulega wyciszeniu [39].

Coraz więcej doniesień sugeruje wielokierunkowe działanie flozyn. Ochrona układu sercowo-naczyniowego, może wynikać z korzystnego wpływu na kontrolę glikemii jak również obniżenia ciśnienia krwi, zmniejszenia obciążenia wstępnego i następczego serca [40]. Równocześnie pośród efektów działania flozyn wymienia się zmniejszenie sztywności tętnic, zapobieganie progresji albuminurii, spadkowi eGFR, jak również działanie natriuretyczne i moczopędne, które jest prawdopodobnie odpowiedzialne za działanie hipotensyjne tych leków [41]. Na podstawie zróżnicowanych efektów sercowo-naczyniowych i nerkowych zasugerowano, że inhibitory SGLT-2 mogą być stosowane do zapobiegania lub leczenia HF u osób z obciążającym wywiadem sercowo-naczyniowym. Ma to odzwierciedlenie w aktualnych wytycznych PTNT (Polskiego Towarzystwa Nadciśnienia Tętniczego) [42].

Inną grupą nowych leków hipoglikemizujących o uznanym działaniu kardioprotekcyjnym są analogi GLP-1 (ang. glucagon like peptide-1). Podkreśla się wielokierunkowe działanie tej klasy leków. Aktywacja farmakologiczna układu GLP-1 wpływa korzystnie na profil lipidowy, zwiększając stężenie HDL, obniżając stężenie TG, równocześnie obniża ciśnienie tętnicze krwi poprzez działanie naczyniorozszerzające [43]. Dalsze badania wykazały działanie kardioprotekcyjnie GLP-1, przeciwzapalne i modulujące czynność śródbłonka naczyniowego [43]. Badania na modelach zwierzęcych, jak i obserwacje kliniczne potwierdziły wpływ GLP-1 na eferentną aktywność współczulną objawiającą się zmniejszeniem ciśnienia tętniczego krwi [43]. Dodatkowo dane uzyskane na modelach zwierzęcych wskazały, korzystny wpływ na wrażliwość mięśnia sercowego na insulinę i poprawę wychwytu glukozy; zwiększenie objętości wyrzutowej i pojemności minutowej serca jak również; zmniejszenie częstości rytmu serca i zwiększenie przeżywalności przez analogi GLP-1 [44-45].

Jakkolwiek znanym jest powszechnie fakt, iż agoniści receptora GLP-1 zwiększają spoczynkową akcję serca, to wpływ na równowagę układu autonomicznego wymaga dalszych badań, gdyż podejrzewa się brak efektu klasy, co potwierdzają zróżnicowane wyniki badań sercowo-naczyniowych (ang. CVOTs - Cardiovascular Outcome Trials) [4648].

\section{LECZENIE PRZYCZYNOWE}

Pomimo znacznego postępu medycyny wciąż brak skutecznego leku dla neuropatii autonomicznej w przebiegu cukrzycy. Leczenie hipotonii ortostatycznej w jej łagodnej formie często polega na postępowaniu zachowawczym, tzn. wystarczające mogą okazać się dieta z podwyższoną zawartością sodu, wzniesienie zagłówka łóżka w trakcie snu lub stosowanie pończoch uciskowych [5,27]. Interwencje farmakologiczne obejmują stosowanie mineralokortykoidów (fludrokortyzon), środków sympatykomimetycznych (klonidyna), b-adrenolityków (propranolol, pindolol), środków presyjnych (kofeina), czy inhibitorów syntezy prostaglandyn (ibuprofen, naproksen) [49]. Dotychczasowe próby zakładające intensywne postępowanie przeciwzapalne czy redukujące stres oksydacyjny za pomocą takich substancji jak kwas alfa-liponowy stosowany $\mathrm{w}$ monoterapii (DEKAN, NATHAN), bądź w skojarzeniu z niacynamidem i allopurinolem przyniosły zróżnicowane efekty [50-52]. Wydaje się jednak, że leczenie objawów NSN tj. spoczynkowej tachykardii, hipotonii ortostatycznej, non/rewers dipping (pacjenci bez nocnego spadku ciśnienia tętniczego krwi/ wzrostem CTK w godzinach nocnych) czy też podwyższonego ciśnienia w pozycji horyzontalnej może być osiągalne i korzystnie wpływać na przeżywalność pacjentów z DM [53-55].

\section{PODSUMOWANIE}

Neuropatia cukrzycowa, w tym autonomiczna neuropatia sercowo - naczyniowa, jest najczęstszym powikłaniem przewlekłym cukrzycy. Powoduje ona poważne konsekwencje zdrowotne i społeczne, prowadząc do istotnego skrócenia oczekiwanej długości życia u pacjentów z DM. Jej rozwój jest początkowo bezobjawowy i przez to często niedoszacowany a jedynie wczesne wykrycie neuropatii cu- 
krzycowej daje realne szanse na zahamowanie jej postępu i zapobiegnięcie nieodwracalnemu uszkodzeniu nerwów.

Najistotniejszym czynnikiem przeciwdziałającym rozwojowi neuropatii, hamującym jej występowanie oraz progresję, jest optymalizacja kontroli glikemii. W fazie zaawansowanej natomiast, pozostają jedynie próby leczenia objawowego.

\section{PIŚMIENNICTWO}

1. World Health Organization. Global exepert on diabetes (2016) https:// apps.who.int/iris/bitstream/handle/10665/204871/9789241565257_ eng.pdf;jsessionid=4637D4059D250B7A5151776A5974DBA3?sequen$\mathrm{ce}=1$

2. Ghasemi H, Afshar R, Zerafatjou N, Abdi S, Davati A, Askari MK, Shabpiray H (2012) Impact of hemodialysis on visual parameters in patients with end-stage renal disease. Iran J Kidney Dis 6: 457

3. Edwards JL, Vincent AM, Cheng HT, Feldman EL (2008) Diabetic neuropathy: mechanisms to management. Pharmacol Therap 120: 1-34

4. Troskot N, Duvančić T, Kolić M (2013) Diabetic foot syndrome - dermatological. Acta Clin Croat 52: 99-106

5. Marciniec M, Nowak A (2017) Neuropatia sercowo-naczyniowa jako kardiologiczne powikłanie cukrzycy: objawy, diagnostyka i leczenie. Kardiologia po Dyplomie, 05 (październik)

6. Spallone V, Ziegler D, Freeman R, Bernardi L, Frontoni S, Pop-Busui R, Stevens M, Kempler P, Hilsted J, Tesfaye S, Low P, Valensi P (2011) Cardiovascular autonomic neuropathy in diabetes: clinical impact, assessment, diagnosis, and management. Diabetes Metab Res Rev 27: 639-53

7. Low PA, Bernrud-Larson LM, Sletten DM, et all (2004) Autonomic symptoms and diabetic neuropathy: a population-based study. Diabetes Care 27: 2942-2947

8. Ziegler D, Voss A, Rathmann W, Strom A, Perz S, Roden M, Peters A, Meisinger C; KORA Study Group (2015) Increased prevalence of cardiac autonomic dysfunction at different degrees of glucose intolerance in the general population: the KORA S4 survey. Diabetologia 58:1118-28

9. Franco OH, Steyerberg EW, Hu FB, Mackenbach J, Nusselder W (2007) Associations of diabetes mellitus with total life expectancy and life expectancy with and without cardiovascular disease. Arch Intern Med 167: 1145-51

10. Fleischer J, Yderstraede K, Gulichsen E, Jakobsen PE, Lervang HH, Eldrup E, Nygaard H, Tarnow L and Ejskjaer N (2014) Cardiovascular autonomic neuropathy is associated with macrovascular risk factors in type 2 diabetes: new technology used for routine large-scale screening adds new insight. J Diabetes Sci Technol 8: 874-880

11. Brownlee M (2001) Biochemistry and molecular cell biology of diabetic complications. Nature 414: 813-817

12. Jack M, Wright D (2012) Role of advanced glycation endproducts and glyoxalase I in diabetic peripheral sensory neuropathy. Transl Res 159: 355-365

13. Kiec-Wilk B, Matejko B, Razny U, Stankiewicz M, Skupien J, Klupa T, Malecki MT (20116) Hypoglycemic episodes are associated with inflammatory status in patients with type 1 diabetes mellitus. Atherosclerosis 251: 334-338

14. Cameron NE, Eaton SE, Cotter MA, Tesfaye S (2001) Vascular factors and metabolic interactions in the pathogenesis of diabetic neuropathy. Diabetologia 44: 1973-1988

15. Hansen CS, Fleischer J, Vistisen D, Ridderstråle M, Jensen JS, Jørgensen ME (2017) High and low vitamin D level is associated with cardiovascular autonomic neuropathy in people with Type 1 and Type 2 diabetes. Diabet Med 34: 364-371

16. Hansen CS, Jensen JS, Ridderstrale M, Vistisen D, Jorgensen ME, Fleischer J (2017) Vitamin B12 deficiency is associated with cardiovascular autonomic neuropathy in patients with type 2 diabetes. J Diabetes Comp 31: 202-208
17. Ling C, Groop L (2009) Epigenetics: A molecular link between environmental factors and type 2 diabetes. Diabetes 58: 2718-2725

18. Hewagama A, Richardson B (2009) The genetics and epigenetics of autoimmune diseases. J Autoimmunity 33: 3-11

19. Pirola L, Balcerczyk A, Okabe J, El-Osta A (2010) Epigenetic phenomena linked to diabetic complications. Nat Rev Endocrinol 6: 665-668

20. Park SY, Jeong HJ, Yang WM, Lee W. (2013) Implications of microRNAs in the pathogenesis of diabetes. Arch Pharm Res 36: 154-166

21. Plaisance V, Waeber G, Regazzi R, Abderrahmani A (2014) Role of microRNAs in islet beta-cell compensation and failure during diabetes. J Diabetes Res 5: 618652

22. Ciccacci C, Morganti R, Di Fusco D, D'Amato C, Cacciotti L, Greco C, Rufini S, Novelli G, Sangiuolo F, Marfia GA, Borgiani P, Spallone V (2014) Common polymorphisms in MIR146a, MIR128a and MIR27a genes contribute to neuropathy susceptibility in type 2 diabetes. Acta Diabetol 51: 663-71

23. Ciccacci C, Latini A, Greco C, Politi C, D'Amato C, Lauro D, Novelli G, Borgiani P, Spallone V (2018) Association between a MIR499A polymorphism and diabetic neuropathy in type 2 diabetes. J Diabetes Comp 32: 11-7

24. Freeman R (2008) Neurogenic orthostatic hypotension. N Engl J Med 358: 615-24

25. Tschöpe C, Van Linthout S (2014) New insights in (inter) cellular mechanisms by heart failure with preserved ejection fraction. Curr Heart Fail Rep 11: 436-444

26. Pawliński Ł, Gastoł J, Fiema M, Matejko B, Kieć-Wilk B (2019) Is treatment of type 1 diabetes mellitus (insulin therapy, metabolic control) optimal for preventing cardiovascular autonomic neuropathy? Endokrynol Pol 70: 323-329.

27. Araszkiewicz A, Bandurska-Stankiewicz E, Budzyński A, Cypryk K, Czech A, Czupryniak L, Drzewoski J i wsp. (2019) Zalecenia kliniczne dotyczące postępowania u chorych na cukrzycę 2019. Stanowisko Polskiego Towarzystwa Diabetologicznego. Diabetologia Praktyczna 5: $1-100$

28. Alam I, Lewis MJ, Lewis KE, Stephens JW, Baxter JN (2009) Influence of bariatric surgery on indices of cardiac autonomic control. Auton Neurosci 151: 168-173

29. Sjoberg N, Brinkworth GD, Wycherley TP, Noakes M, Saint DA (2011) Moderate weight loss improves heart rate variability in overweight and obese adults with type 2 diabetes. J Appl Physiol 110: 1060-1064

30. Ziegler D, Strom A, Nowotny B, Zahiragic L, Nowotny PJ, Carstensen-Kirberg M, Herder C, Roden M (2015) Effect of low-energy diets differing in fiber, red meat, and coffee intake on cardiac autonomic function in obese individuals with type 2 diabetes. Diabetes Care 38: 1750-1757

31. Hansen AL, \& Grung B (2016) Fish consumption and heart rate variability, W: Raatz SK, Bibus DM (red) Fish and Fish Oil in Health and Disease Prevention. Academic Press, str. 231-238

32. Sauder KA, McCrea CE, Ulbrecht JS, Kris-Etherton PM, West SG (2014) Pistachio nut consumption modifies systemic hemodynamics, increases heart rate variability, and reduces ambulatory blood pressure in well-controlled type 2 diabetes: a randomized trial. J Am Heart Assoc 3: e000873

33. Villafaina S, Collado-Mateo D, Fuentes JP, Merellano-Navarro E, Gusi N (2017) Physical exercise improves heart rate variability in patients with type 2 diabetes: a systematic review. Curr Diab Rep 17: 110 - 114

34. de Pablos-Velasco P, Ricat W, Mnero S i wsp. (2003) The Relation between physical activity and metabolic control in type 2 diabetes with $<20$ years of evolution. Diabetes Care 26: 1648-1650

35. Singh S, Malhotra V, Singh KP, Madhu SV, Tandon OP (2004) Role of yoga in modifying certain cardiovascular functions in type 2 diabetic patients. J Assoc Physicians India 52: 203- 206

36. Martin CL, Albers JW, Pop-Busui R (2014) DCCT/EDiC research Group. Neuropathy and related findings in the diabetes control and complications trial/epidemiology of diabetes interventions and complications study. Diabetes Care 37: 31-38 
37. Strojek K (2016) Empagliflozyna. Wyniki badania EMPA-REG OUTCOME. Przełom w leczeniu cukrzycy typu 2? Clin Diabet 3: 107-110

38. Zinman B, C Wanner, John M. at all (2015) Empagliflozin, Cardiovascular Outcomes, and Mortality in Type 2 Diabetes. N Engl J Med 373: 2117-2128

39. Sano M (2018) A new class of drugs for heart failure: SGLT2 inhibitors reduce sympathetic overactivity. J Cardiol 71: 471-476

40. Bonora BM, de Kreutzenberg SV, Avogaro A, Fadini GP (2019) Effects of the SGLT2 inhibitor dapagliflozin on cardiac function evaluated by impedance cardiography in patients with type 2 diabetes. Secondary analysis of a randomized placebo-controlled trial. Cardiovasc Diabetol 18: $106-110$

41. Aroor AR, Das NA, Carpenter AJ, Habibi J, Jia G, Ramirez-Perez FI, Martinez-Lemus L, Manrique-Acevedo CM, Hayden MR, Duta C, Nistala R (2018) Glycemic control by the SGLT2 inhibitor empagliflozin decreases aortic stiffness, renal resistivity index and kidney injury. Cardiovasc Diabetol 17: 108-112

42. Tykarski A, Narkiewicz K, Gaciong Z, Januszewicz A, Litwin M, Kostka-Jeziorny K (2019) Zasady postępowania w nadciśnieniu tętniczym - 2019 rok. Nadciśnienie Tętnicze w Praktyce 5: 87-98

43. Chłopicki S (2009) Śródbłonek w chorobach układu krążenia. Kardiologia Po Dyplomie $870-83$

44. Zhao T, Parikh P, Bhashyam S, Bolukoglu H, Poornima I, Shen YT, Shannon RP (2006) Direct effects of glucagon-like peptide-1 on myocardial contractility and glucose uptake in normal and postischemic isolated rat hearts. J Pharmacol Exp Ther 317: 1106-1113

45. Poornima I, Brown SB, Bhashyam S, Parikh P, Bolukoglu H, Shannon RP (2008) Chronic glucagon-like peptide-1 infusion sustains left ventricular systolic function and prolongs survival in the spontaneously hypertensive, heart failure-prone rat. Circ Heart Fail 1: 153-60

46. Cacciatori V, Zoppini G, Bellavere F, Rigolon R, Thomaseth K, Pichiri I, Trombetta M, Dauriz M, De Santi F, Targher G, Santi L (2017) Long-acting GLP-1 receptor agonist exenatide influence on the autonomic cardiac sympatho-vagal balance. J Endocr Soc 2: 53-62

47. Nakatani Y, Kawabe A, Matsumura M, Aso Y, Yasu T, Banba N, Nakamoto T (2016) Effects of GLP-1 receptor agonists on heart rate and the autonomic nervous system using Holter electrocardiography and power spectrum analysis of heart rate variability. Diabetes Care 39: e22-23

48. Smits MM, Muskiet MH, Tonneijck L, Hoekstra T, Kramer MH, Diamant M, van Raalte DH (2016) Exenatide acutely increases heart rate in parallel with augmented sympathetic nervous system activation in healthy overweight males. Brit J Clin Pharm 81: 613-620

49. Szczyrba S, Kozera G, Bieniaszewski L, Nyka WM (2010) Neuropatia cukrzycowa- patogeneza, rozpoznawanie, zapobieganie, leczenie. Forum Medycyny Rodzinnej 4: 339-355

50. Ziegler D, Schatz H, Conrad F, Gries FA, Ulrich H, Reichel G, DEKAN Study Group (1997) Effects of treatment with the antioxidant a-lipoic acid on cardiac autonomic neuropathy in NIDDM patients: a 4-month randomized controlled multicenter trial (DEKAN Study). Diabetes Care 20: 369-373

51. Ziegler D, Low PA, Freeman R, Tritschler H, Vinik AI (2016) Predictors of improvement and progression of diabetic polyneuropathy following treatment with a-lipoic acid for 4 years in the NATHAN 1 trial. J Diabetes Comp 30: 350-356

52. Pop-Busui R, Stevens MJ, Raffel DM, White EA, Mehta M, Plunkett CD, Brown MB, Feldman EL (2013) Effects of triple antioxidant therapy on measures of cardiovascular autonomic neuropathy and on myocardial blood flow in type 1 diabetes: a randomised controlled trial Diabetologia 56: 1835-1844

53. Gibbons $\mathrm{CH}$, Schmidt P, Biaggioni I, Frazier-Mills C, Freeman R, Isaacson S, Karabin B, Kuritzky L, Lew M, Low P, Mehdirad A (2017) The recommendations of a consensus panel for the screening, diagnosis, and treatment of neurogenic orthostatic hypotension and associated supine hypertension. J Neurol 264: 1567-1582

54. Fanciulli A, Jordan J, Biaggioni I, Calandra-Buonaura G, Cheshire WP, Cortelli P, Eschlboeck S, Grassi G, Hilz MJ, Kaufmann H, Lahrmann $\mathrm{H}$ (2018) Consensus statement on the definition of neurogenic supine hypertension in cardiovascular autonomic failure by the American Autonomic Society (AAS) and the European Federation of Autonomic Societies (EFAS). Clin Auton Res 28: 355-362

55. Rossen NB, Knudsen ST, Fleischer J, Hvas AM, Ebbehøj E, Poulsen PL, Hansen KW (2014) Targeting nocturnal hypertension in type 2 diabetes mellitus. Hypertension 64: 1080-1087

\title{
Cardiovascular autonomic neuropathy in the course of diabetes - the review of actual knowledge
}

\author{
Joanna Gastol ${ }^{1}$, Łukasz Pawliński ${ }^{1}$, Beata Kieć-Wilk ${ }^{1,2} \llbracket$
}

University Hospital in Krakow, Department of Metabolic Diseases, Medical College Jagiellonian University, Kraków, Poland

Key words: autonomic cardiovascular neuropathy, diabetes mellitus, epigenetics, treatment

${ }^{\square}$ Corresponging author: mbkiec@gmail.com

\section{SUMMARTY}

Diabetic neuropathy, including autonomic cardiovascular neuropathy, is the most common chronic complication of diabetes. It causes serious health and social consequences, leading to a significant reduction of life expectancy in DM patients. Its development is initially asymptomatic and therefore often underestimated, and only the early detection of diabetic neuropathy gives a real chance to stop its progression and prevent irreversible damage of the nerves. The optimal glycemic control is the most important factor preventing the development of neuropathy, inhibiting its occurrence and progression. In the advanced stage, however, only symptomatic treatment remains.

The article provides an overview of current knowledge about etiopathogenesis, therapy, symptoms and the latest clinical trials on NSN and DM. 